\title{
ASSESSING THE WTO COMPLIANCE OF SELECTED ASPECTS OF SOUTH AFRICA'S INTERNATIONAL TRADE ADMINISTRATION AMENDMENT BILL*
}

\author{
Lonias Ndlovu \\ Dip Ed LLB LLM \\ Department of Private Law \\ University of Zululand
}

\section{SUMMARY}

This article argues that while South Africa's International Trade Administration Amendment Bill and the attendant proposed regulations may generally be regarded as a positive legislative intervention, to a large extent, the new regulatory regime goes against the spirit, object and purport of the World Trade Organization (WTO) anti-dumping agreement and is even in conflict with South Africa's International Trade Administration Act ${ }^{1}$ itself. In order to substantiate the above reservations, this article first outlines the basics of WTO dumping and anti-dumping law before proceeding to point out aspects of South Africa's anti-dumping law and practice which incorporate WTO tenets. With the aid of selected WTO disputes and examples from comparative WTO member states, this article also comments on selected impugned changes likely to be introduced by the Bill and the new regulations and concludes that the proposed new law is unlikely to be WTO compliant. This conclusion is premised on the fact that South African dumping and anti-dumping law relating to confidentiality, the process of conducting investigations, termination of investigations based on de minimis margins and interested party hearings does not always mimic the legal position as espoused in the WTO anti-dumping agreement and interpreted in selected WTO disputes.

\section{INTRODUCTION}

In comparison with other African states and the rest of the global community, South Africa has one of the most widespread and documented histories of applying anti-dumping measures. ${ }^{2}$ South Africa's anti-dumping laws date

This is a revised version of an earlier paper which was presented at the Annual Congress of the Society of Law Teachers of Southern Africa hosted by the Faculty of Law, University of KwaZulu Natal, Pietermaritzburg, South Africa from 13-16 July 2009. I am very grateful to Dr WJ Ndaba, a colleague in the Department of Private Law for reading and making corrections to an earlier draft of this article.

71 of 2002.

2 See generally Joubert "The Reform of South Africa's Anti-Dumping Regime" http://www.wto.org/english/res e/booksp_e/casestudies_e/case38 e.htm (accessed 200907-01); Tao Dumping and Anti-Dumping Regulations with Specific Reference to the Legal Framework in South Africa and China (2006) LLM dissertation, University of the Free State; 
back to $1914 ;^{3}$ and the first anti-dumping duties are said to have been imposed in $1921 .{ }^{4}$ In all documented appearances of South before WTO panels, South Africa appeared only as a respondent ${ }^{6}$ and the subject matter was dumping/anti-dumping. ${ }^{7}$

In October 2005, South Africa published the draft International Trade Administration Amendment Bill ${ }^{8}$ for public comment. ${ }^{9}$ Broadly speaking, the Bill seeks to revise South Africa's Anti-Dumping Regulations ${ }^{10}$ and incorporate the lessons learnt by the authorities in the application of the regulations thus far.

Firstly, and perhaps most importantly, it has been argued that the Bill will align South Africa's Anti-Dumping Regulations in sympathy with its WTO obligations. ${ }^{11}$ Secondly, it is the Bill's intention to streamline processes and

and Brink and Kobayashi "South Africa" in Nakagawa Anti-Dumping Laws and Practices of the New Users (2007) 203. According to Macrory, Appleton and Plummer The World Trade Organization: Legal, Economic and Political Analysis (2005) 45, in 1958 GATT members had only 37 anti-dumping measures in force and South Africa alone accounted for 32.

3 S 8(1) of the Customs Tariff Act 26 of 1914

4 See Board Report No. 42 (dumping or unfair Competition 18/11/1924) in which reference was made to an imposition of anti-dumping duties on flour from Australia in 1921.

5 Established on 1 January 1995, the World Trade Organization provides a forum for implementing the multilateral trading system, negotiating new trade agreements and resolving trade disputes.

6 It is noteworthy to point out that South Africa has never brought a complaint to the WTO about a trade measure taken by any of its trading partners. The notable trend has been that South Africa has always appeared before WTO panels as the party complained against in anti-dumping matters. It has generally been argued by Busch and Reinhardt "Developing Countries and General Agreement on Tariffs and Trade/World Trade Organization Dispute Settlement" 200337 Journal of World Trade 719720 that the extent of a country's participation in the WTO dispute settlement system is a reliable indicator of the level of its economic activity. Appearing only as respondent is not healthy because this points at the fact that there are a number of weaknesses in your legal system which your trading partners always complain about.

7 The pertinent disputes are South Africa - Anti-dumping Duties on Certain Pharmaceutical Products from India, DS168, South Africa - Definitive Anti-Dumping Measures on Blanketing from Turkey, DS288 and South Africa - Anti-Dumping Measures on Uncoated Woodfree Paper, DS374. It may be noted that in all the three disputes, the matters did not go beyond the "request for consultation" stage since South Africa successfully wriggled her way out of trouble through diplomatic overtures. Specifically, in the first case in which India was the complainant, consultations were requested but no panel was established nor any settlement notified. In the second case involving South Africa and Turkey, similarly, consultations were requested but no panel was established nor any settlement notified. In the last case, on 20 November 2008, Indonesia informed the Dispute Settlement Body that South Africa had promulgated an amendment to the Schedule of the Customs and Excise Act withdrawing the anti-dumping measures imposed on uncoated woodfree white A4 paper from Indonesia with retrospective effect from 27 November 2003.

8 See GN 1867 in GG 28137 of 2005-10-14

9 Ss 59 and 72 of the Constitution of South Africa 1996 enjoin the National Assembly and the National Council of Provinces respectively to facilitate public involvement in the legislative and other processes of the two houses including committees.

10 See GN 3197 in GG 25684 of 2003-11-14. The full text of the Regulations http://www. itac.org.za/documents/Notice\%203197(Anti-dumping).pdf (accessed 2009-08-18).

11 See generally Floor Inc Attorneys "Anti-dumping Regulations to be Revised" http://www. floor-inc.co.za/news/article.asp?news $I D=119$ (accessed 2009-06-08). In terms of principles outlined in Article 1 of the Agreement on the Implementation of Article VI of the General 
procedures in order to alleviate what the International Trade Administration Commission (ITAC) ${ }^{12}$ sees as an overload on their capacity brought about by the present operation of the regulations. ${ }^{13}$

While the Bill may generally be regarded as a positive intervention because the proposed changes are aimed at WTO compliance and improvement of the current law, this article argues that to a large extent, the amendments to selected anti-dumping regulations go against the object and purport of the WTO anti-dumping agreement. ${ }^{14}$ Further, the amendments conflict with South Africa's international Trade Administration Act. ${ }^{15}$ The reservations made above are specifically directed at general provisions relating to confidentiality, ${ }^{16}$ investigations,$^{17}$ termination based on de minimis margins ${ }^{18}$ and interested party hearings. ${ }^{19}$ In order to substantiate the above reservations, this article first outlines the basics of WTO anti-dumping law as proposed in the amending Bill and then proceeds to critique aspects of South Africa's anti-dumping law and practice which do not seem to incorporate WTO compliant procedures. Finally, through the aid of selected

Agreement on Tariffs and Trade (hereinafter "Anti-Dumping Agreement"), all forms of action taken under anti-dumping legislation or regulations must be conducted in accordance with the WTO agreement. Such principles include but are not limited to confidentiality, carrying out investigations, termination of investigations and interested party hearings.

12 The International Trade Administration Commission is a juristic person established in terms of Chapter 3 of the International Trade Administration Act 71 of 2002 (hereinafter "ITAC"). The body's major functional hallmarks include the administration of trade remedies such as anti-dumping duties and safeguard measures. In terms of $s 7$ of the Act, ITAC has jurisdiction over the whole of South Africa and must exercise its functions in accordance with the Act and any other relevant law. The powers and functions of ITAC are spelt out in ss 15 to 22 of the ITAC Act.

13 The most comprehensive and widely available commentary on the proposed amendments to the regulations is Brink's work Proposed Amendments to the Anti-Dumping Regulations: Are the Amendments in Order? (2006) Tralac Working Paper No. 21.

14 See fn 11 above. According to Article VI of the General Agreement on Tariffs and Trade 1994 (hereinafter "GATT 1994"), dumping must be condemned if it causes or threatens material injury to an established industry in the territory of a contracting party or materially retards the establishment of a domestic industry. It is submitted that having a regulatory regime that does not comply with basic WTO tenets such as the respect for confidentiality in anti-dumping investigations is against the object and purport of the WTO Anti-Dumping Agreement.

1571 of 2002. For instance, the provisions in s 33 of the ITAC Act relating to confidential information conflict with those proposed by section 11 of the proposed Amendment Bill. The conflict arises because the later now does away with the provision of sworn statements explaining why the deponent could not supply a non-confidential summary of the information in requested.

16 The importance of confidentiality may be aptly amplified by the fact that in Article 6 of the Anti-Dumping Agreement, the issue is mentioned thrice (in 6.1.2, 6.2 and 6.5). S 33(1)(a)(b) of the ITAC Act and $s 2$ of the current Anti-Dumping regulations deal specifically with confidentiality.

17 Article 5 of the Anti-Dumping Agreement and current Anti-Dumping Regulations 3.2 and 3.2(b).

18 Article 5.8 of the Anti-Dumping Agreement and Article 4 of the proposed Anti-Dumping Regulations.

19 Article 6.11 of the Anti-Dumping Agreement and Regulation 6 of the proposed Anti-Dumping Regulations. 
WTO jurisprudence, ${ }^{20}$ this article also comments on pertinent impugned changes encapsulated in the Bill, and concludes that as far as the specified matters ${ }^{21}$ are concerned, the new law is unlikely to be WTO compliant.

\section{BASIC ISSUES IN DUMPING AND ANTI-DUMPING LAW}

\section{General definitional and conceptual issues}

In international trade law governed by the WTO, the law relating to dumping is encapsulated in Article VI of GATT $1994^{22}$ and the subsequent AntiDumping Agreement. ${ }^{23}$ Dumping is said to take place when a product is introduced into the commerce of another country at less than its normal value ${ }^{24}$ Normal value is normally defined as the selling price in the country of export. ${ }^{25}$

In order to allege that dumping has occurred, the affected entity has to lead evidence proving that imports are being introduced at less than normal value; further that such imports cause or threaten to cause material injury to local industry producing like products. ${ }^{26}$ In specific context of dumping, the term "like product" shall be interpreted to mean a product which is identical (like in all respects) to the product under consideration. ${ }^{27}$ If there is no

20 See paragraph 4 below which provides pertinent commentary on selected disputes in the proper context of the scope of this article.

21 The specific matters this article seeks to interrogate are confidentiality, termination based on de minimis margins, investigations and interested party hearings.

22 The agreement establishing the World Trade Organization, which was signed in Marrakesh, Morocco in 1994, incorporates the original General Agreement on Tariffs and Trade 1947 (hereinafter "GATT"), which continues to apply to issues not covered by the more specific agreements negotiated during the Uruguay round. GATT 1994 in this article refers to GATT 1947 and other agreements concluded after 1994. Article VI allows governments to take action against dumping and the Anti - Dumping Agreement details how such action may be taken. The two instruments must be read together as contemporaneous documents.

23 Agreement on Implementation of Article VI of the General Agreement on Tariffs and Trade 1994.This Agreement is listed in Annex 1A of The Legal Texts the Results of the Uruguay Round of Multilateral Trade Negotiations (1999) as one of the Multilateral Agreements on Trade in Goods. A full text of the agreement of the Legal Texts 147-171.

24 Per Article 2.1 of the Agreement. According to Osode "An Assessment of the WTOConsistency of the Procedural Aspects of South African Anti-Dumping Law and Practice" 200322 Penn State International Law Review 19, there is an additional form of dumping characterized as "below cost sales" or simply "cost dumping", which involves the sale of products in an export market at prices below their production cost.

25 See Brink (fn 13 above) 1.

26 World Trade Organization Understanding the WTO (2007) 44-45.The WTO Appellate Body had an opportunity to pronounce on material injury generally and the factors determining injury in Thailand - Anti-Dumping Duties on Angles, Shapes and Sections of Iron or NonAlloy and H-Beams from Poland, WT/DS122/AB/R, adopted 5 April 2001 in which Poland complained that Thailand had not calculated its dumping margin correctly and that the Thai investigating authorities had not considered all injury factors. The Appellate Body ruled in favour of Thailand on the issue of the calculation of the dumping margin, but ruled against the same country on injury factors.

27 Article 2.6 of the Anti-Dumping Agreement. 
identical product as pointed out above, "like product" would be taken to mean another product which, although not alike in all respects, has characteristics closely resembling those of the product under consideration. ${ }^{28}$

Therefore, the WTO Agreement, often called the "Anti-Dumping Agreement", allows governments to act against dumping where there is genuine ("material") injury to competing domestic industry. ${ }^{29}$ The AntiDumping Agreement does not outlaw dumping as such ${ }^{30}$ but prescribes how governments can or cannot react to dumping. ${ }^{31}$ Why dumping occurs is not considered relevant under WTO rules. ${ }^{32}$ Additionally, it has been argued that there is no textual basis in Article $\mathrm{VI}$ for the view that states harboured an intention to include other forms of dumping such as "social" dumping. ${ }^{33}$

Despite the foregoing remarks, there are three main reasons for the widespread disapproval of dumping. ${ }^{34}$ Firstly, it has often been argued that dumping has the effect of distorting market fundamentals because it enables an exporter to gain market share in an importing country without necessarily being an efficient producer. ${ }^{35}$

Secondly, dumping is said to contribute to a form of unfair competition/unfair trade because the perpetrators thereof are exporters who enjoy the special privileges on the domestic market on which they can charge very high prices while banking on the absence of "real"36 competition

28 Ibid. In the context of anti-dumping, the concept was litigated in the WTO dispute of US Softwood Lumber V, Appellate Body Report, United States - Final Dumping Determination on Softwood Lumber from Canada, WT/DS2264/AB/R, adopted 31 August 2004, DSR 2004:V, 18.

29 Understanding the WTO (fn 26 above) 44. In South Africa, domestic industry refers to the relevant industry in the Southern African Customs Union (SACU). According Lehloenya "The Failed SACU-USA Trade Agreement in Hindsight: A lost Opportunity or Disaster Averted? 20094 Journal of International Commercial Law and Technology 117. SACU is a regional body comprising Botswana, Lesotho, Namibia, South Africa and Swaziland.

30 See Horlick and Clarke "Standards of Panels Reviewing Anti-Dumping Determinations under the GATT and WTO" in Bronkers and Horlick (eds) WTO Jurisprudence and Policy: Practitioners' Perspectives (2004) 115.

31 Ibid.

32 Hoekman and Kostecki The Political Economy of the World Trading System: the WTO and Beyond (2003) 318-320. The authors, however, argue that from a normative, economic perspective, it is important to know why dumping occurs. The reasons for dumping will point at a typology of business motivation for dumping such as profit maximization, maintaining capacity during periods of slack demand, deterring entry by competitors, creating new markets, attacking a dominant supplier in an export market or even attempting to establish a monopoly on an export market.

33 See generally Johnson World Trade and the Law of GATT (1969); and Mavroidis Trade in Goods: The GATT and Other Agreements Regulating Trade in Goods (2007). Johnson (674) cites as an example of social dumping a scenario in which work is done in iniquitous conditions in order to make products which can be sold at a lower price compared to that which can be required by the observance of the minimum international labour standards.

34 Johnson Legal Problems of International Economic Relations (1995) 671-683.

35 Osode 200322 Penn State International Law Review 19.

36 Competition may be absent either due to the fact that there is no domestic industry producing like products because its establishment is being frustrated by the availability of cheap competing imports or the domestic industry does exist but produces on a small scale which does not satisfy local demand for the product in question. 
in the importing country. ${ }^{37}$ This scenario would be more than likely in the absence of arbitrage opportunities for competitors in the importing country.

Finally, dumping can produce overwhelmingly negative consequences for the government of the importing country, its domestic producers and the general public. ${ }^{38}$ Indicators of the presence of negative consequences may be the shrinkage of the market share for the locally produced product leading to cuts in its local production and a reduction of the number of employees employed in that type of industry. ${ }^{39}$

The above negatives notwithstanding, anti-dumping measures remain a prominent feature of contemporary international trade regulation largely due to the immense political support they enjoy. ${ }^{40}$ The political support for antidumping actions may be motivated by governments' need to protect domestic industries that are threatened by cheap imports. It is reasonable to assume that the development of the economy through industrialization will in turn spur development in other spheres such as innovation, job creation, social and political stability. The result is that overall productivity and investment strength of the domestic industry may be weakened. The law therefore jealously guards the status quo by ensuring that in addition to escape clauses/safeguards, ${ }^{41}$ anti-dumping measures ensure the preservation of certain strategic local industries by keeping cheap imports out.

There are certain ways of establishing whether or not a product is being dumped lightly or heavily. ${ }^{42}$ The Anti-Dumping Agreement provides three methods to calculate the products' normal value. ${ }^{43}$ The main method uses the exporter's selling price in the domestic market ${ }^{44}$ of the importing/complaining country. If the exporter's selling price in the domestic market cannot be used, ${ }^{45}$ then the next method is to use the price charged

37 Osode 200322 Penn State International Law Review 19.

38 The extreme effects that easily come to mind are the possible demise of governments through debilitating strikes, massive unemployment, civil unrest by the citizenry and the shrinkage of domestic manufacturing caused by cheap imports.

39 Hoekman and Kostecki 324.

40 Osode 200322 Penn State International Law Review 2.

41 Article XIX of GATT 1994. Safeguard measures may be deployed in response to "fairlytraded imports" in situations where import volumes have tremendously increased to such an extent that the increased imports injure producers of "like or directly competitive products". This would be the case where import volumes increase but not as a result of dumping. The form of injury that will trigger the application of the provisions of Article XIX of GATT 1994 is one that is characterized as "serious".

42 See Articles 3.2 and 3.3 of the Anti-Dumping Agreement. Light dumping is a from of dumping that is not very significant and against which authorities may not take action. This form of dumping would yield a de minimis dumping margin (see paragraphs 323 and 4 below). On the other hand, heavy dumping is the one that threatens the existence of the domestic industry or frustrates its development as outlined in Articles 3.4-3.8 of the AntiDumping Agreement.

43 Generally canvassed in Article 2 of the Anti-dumping Agreement.

44 Article 2.1.

45 Article 2.3. This impossibility may be occasioned by the absence of reliable data or because the exporter and importer have an association arrangement in terms of which the exporter compensates the importer to offset the price gap. This would be tantamount to an artificial manipulation of the dumping margin. 
by an exporter in another country. ${ }^{46}$ The third method is to use, as a basis of calculation the exporter's production costs, other expenses and normal profit margins. ${ }^{47}$ The Anti-Dumping Agreement also specifies how a fair comparison can be made between the export price and what would be a normal price. A comparison between the export price and the normal value will yield the "dumping margin". ${ }^{48}$

Detailed procedures are set out on how anti-dumping investigations, which, barring the existence of special circumstances must be concluded within one year. ${ }^{49}$ Conditions for initiating investigations, conducting them and ensuring that interested parties are given an opportunity to present evidence are provided for. ${ }^{50}$ Anti-dumping measures must expire five years after the date of imposition, unless an investigation shows that ending the measure would lead to injury. ${ }^{51}$ To prevent a proliferation of vexatious and baseless investigations and obviate the potential and actual abuse of process, the Anti-Dumping Agreement enjoins the authorities to examine the accuracy and adequacy of the evidence provided in the application in order to determine whether there is sufficient evidence to justify the initiation of an investigation. ${ }^{52}$ This requirement has been addressed in a number of WTO disputes. ${ }^{53}$

Article 2.2

47 Article 2.4

48 A dumping margin, described by Horlick and Shea "The World Trade Organization Antidumping Agreement" in Bronckers and Horlick WTO Jurisprudence and Policy: Practitioners' Perspectives (2004) 418 as "a comparison of individual prices to individual prices or weighted - average prices to weighted - average prices", assists authorities in deciding whether or not to take action against the alleged dumping activity based on whether the alleged dumping is significant or de minimis.

49 Article 5.10 of the Anti-Dumping Agreement.

50 See Articles 5 and 6 of the Anti-Dumping Agreement.

51 Article 11.3 of the Anti-Dumping Agreement. This refers to the so-called "sunset provision", now entrenched in GATT 1994 but conspicuously absent in the 1979 anti-dumping code which simply provided in Article 9 that, "an anti-dumping duty shall remain in force only as long as, and to the extent necessary to counteract dumping which is causing injury" (author's own emphasis). For a detailed account of the negotiating history of the WTO antidumping law see Horlick and Shea 394-416.

52 See Article 5.3 of the Anti-Dumping Agreement. In South Africa, the competent body to undertake these investigations would be the International Trade Administration Commission (ITAC). In the South African context, this was emphasized in the recent Constitutional Court case of International Trade Administration Commission v SCAW South Africa (Pty) Ltd 2010 5 BCLR 457 (CC) par 25-40.

53 The following disputes are pertinent in this regard: Mexico - Corn Syrup, Panel Report, Mexico - Anti-Dumping Investigation of High Fructose Corn Syrup (HFCS) from the United States, WT/DS132/R and Corr. 1, adopted 24 February 2000, DSR 2000:III, 1345; Guatemala - Cement II, Panel Report, Guatemala - Definitive Anti-Dumping Measures on Grey Portland Cement from Mexico, WT/DS156/R, adopted 17 November 2000, DSR 2000: XI, 5295; Argentina -Poultry, Panel Report, Argentina - Definitive Anti-Dumping Duties on Poultry from Brazil, WT/DS241/R, adopted on 19 May 2003, DSR 2003:V, 1727; AntiDumping Duties, US - Softwood Lumber IV, Appellate Body Report, United States - Final Countervailing Duty Determination with Respect to Certain Softwood Lumber from Canada, WT/DS257/AB/R, adopted 17 February 2004, DSR 2004:II, 571; US - Softwood Lumber V, Appellate Body Report, United States - Final Dumping Determination on Softwood Lumber from Canada, WT/DS2264/AB/R, adopted 31 August 2004, DSR 2004:V, 1875; US-DRAMS, Panel Report, United States - Anti-Dumping Duty on Dynamic Random Access Memory 
WTO members are urged to bring their Anti-Dumping laws and regulations into conformity with the Anti-Dumping agreement. ${ }^{54}$ This requirement was emphasized in the cases of US-1916 Act ${ }^{55}$ and US-Steel, ${ }^{56}$ in which the complainants in both cases alleged that the United States antidumping measures complained of, did not conform to WTO standards. Further, members must inform the WTO Committee on anti-dumping practices taking into account all the preliminary and final anti-dumping actions, promptly and in detail. ${ }^{57}$ South Africa has always strictly adhered to the requirements of Article VI of GATT 1994 and the Anti-Dumping Agreement, especially the notice requirements. ${ }^{58}$

\section{The South African legal framework}

\section{Overview}

South Africa has been a member of the WTO since 1 January $1995 .^{59}$ Although all the WTO agreements were ratified by the country's parliament, ${ }^{60}$ they still do not form part of South African public law. The reason is that the agreements are yet to be promulgated as South African municipal law. ${ }^{61}$ In the case of Progress Office Machines, ${ }^{62}$ the Supreme Court of Appeal correctly concluded that, although the Anti-Dumping Agreement has not been specifically enacted into municipal law, its provisions are binding on the Republic in international law.

The legal regime regulating dumping/anti-dumping in South Africa is encapsulated in the GATT 1994 and the attendant agreement, the

Semiconductors (DRAMS) of One Megabit or Above from Korea, WT/DS99/R, adopted 19 March 1999, DSR 1999:II, 521 and Mexico - Anti-Dumping Measures on Rice, Appellate Body Report, Mexico - Anti-Dumping Measures on Beef and Rice, Complaint with Respect to Rice, WT/DS295/AB/R, adopted 10 January 2001, DSR 2001:I, 5.

54 Article 18.4 of the Anti-Dumping Agreement. The Article enjoins each member to take all the necessary steps of a general or particular nature, to ensure that its laws, regulations and administrative procedures, are in conformity with the provisions of the Anti-Dumping Agreement before entry into force of the WTO Agreement.

55 Appellate Body Report, United States - Anti-Dumping Act of 1916, WT/DS136/AB/R, WT/DS34/AB/R, adopted 26 September 2000, DSR 2000:X, 4793.

56 Panel Report, United States - Anti-Dumping and Countervailing Measures on Steel Plate from India, WT/DS206/R and Corr1, adopted 29 July 2002, DSR 2002: VI, 2073.

57 Article 18.4 of the Anti-dumping Agreement. See also Understanding the WTO (fn 26 above) 45 .

58 Joubert (fn 2 above) 3. Eg, in 1996 announced to the WTO Committee on Anti-dumping Practices that it intended to amend its legislation on anti-dumping to ensure compliance with the relevant WTO Agreements. The amendments gave birth to International Trade Administration Act, ITAC and the anti-dumping regulations of 1993, in force up to date.

59 WTO, "South Africa and the WTO" http://www.wto.org/english/thewto_e/countries_e/ south_africa_e.htm (accessed 2009-09-01).

60 Such ratification is provided for in terms of $s 231$ of the Constitution of the Republic of South Africa, 1996.

61 See Joubert (fn 2 above) 2.

62 Progress Office Machines CC V South African Revenue Services 20082 SA 13 (SCA) par 6. 
constitution, ${ }^{63}$ the Customs and Excise Act, ${ }^{64}$ the International Trade Administration Act (ITAC Act) ${ }^{65}$ and the accompanying Regulations. ${ }^{66}$ With specific regard to dumping/anti-dumping, South Africa's Minister of Trade and Industry will make the regulations pursuant to the provisions in section 59 of the ITAC Act. ${ }^{67}$ South Africa's first Anti-Dumping Regulations were passed on the 14 November 2003. ${ }^{68}$ Since November 2005, proposed amendments to the Anti-Dumping Regulations have been published for public comment. $^{69}$

\section{The salient constitutional provisions}

Despite the fact that the WTO Agreements are yet to be promulgated as South African municipal law, the Constitution explicitly states that international agreements ${ }^{70}$ should be used as references and guidelines in the interpretation of domestic laws. ${ }^{71}$ In this regard, the following constitutional provisions are worth highlighting. ${ }^{72}$

An international agreement binds the Republic of South Africa only after it has been approved by resolution in both the National Assembly and the National Council of Provinces, ${ }^{73}$ unless it is an agreement of a technical, administrative or executive nature. ${ }^{74}$

63 Constitution of the Republic of South Africa, 1996.

6491 of 1964.

6571 of 2002 .

66 In terms of s 59 of the ITAC Act, the Minister (Minister of Trade and Industry) may make regulations regarding the proceedings and functions of the Commission, after consulting the commission (s 59 (a)); give effect to the objects of the ITAC Act (s 59 (b)); and give policy directives on any matter that may or must be prescribed in terms of the Act (s 59 (c)).

67 Specifically, ss 59(b) and 59(c) of the ITAC Act.

68 The Regulations GN 3197 in GG 25684 of 203-11-14.

69 Per e-mail correspondence (30 March 2009) between the present writer and Advocate Niki Kruger, principal legal adviser to the International Trade Administration Commission.

70 Such Agreements would logically include the WTO since South Africa has been a member thereof since 1994 .

71 See s 233 of the South African Constitution 1996 (hereinafter "the Constitution"). On a related note, see also Stemmet, "The Influence of Recent Constitutional Developments in South Africa on the Relationship between International Law and Municipal Law" 199933 International Lawyer 47.

72 The following account draws largely from Burrell Burrell's South African Patent and Design Law 3ed (2000) 14-15.

73 According to Rautenbach and Malherbe Constitutional Law 5ed (2008) 122-123, the present South African parliament consists of two houses, namely the National Assembly and the National Council of Provinces. The National Assembly consists of directly elected legislators who are elected through a process of proportional representation of all the political parties involved in the general election. The National Council of Provinces represents the provinces in parliament and ensures that provincial interests are taken into account in the national sphere. For a complete exposition of the current South African parliamentary system, see generally Taljaard and Venter "Parliament" in Venter (ed) Government and Politics in the New South Africa (2001) 15-27.

$74 \mathrm{~S} 231(2)$ of the Constitution. For an outline of the origin, academic debates and analysis of the provisions of this section generally and s 231(2) in particular see Dugard "International Law and the South African constitution" 19978 European Journal of International Law 77; Olivier "The Status of International Law in South African Municipal Law: Section 231 of the 
International agreements of a technical, administrative and executive nature or agreements that do not require either ratification or accession, entered into by the national executive, bind the Republic without approval by the National Assembly or the National Council of Provinces. The only requirement is that they must be tabled in the National Assembly and National Council of Provinces within a reasonable time. ${ }^{75}$

Any international agreement becomes law in the Republic when it is enacted into law by the national legislation; but a self-executing provision of an agreement that has been approved by parliament is law in the Republic unless it is inconsistent with the Constitution or an Act of parliament. ${ }^{76}$

The Republic of South Africa is bound by international arrangements which were binding on the Republic on 4 February $1997^{77}$ and customary international law is law in the Republic unless it is inconsistent with the South African Constitution or an Act of parliament. ${ }^{78}$

When interpreting any legislation, South African courts must prefer any reasonable interpretation of the legislation which is consistent with international law over any alternative interpretation that is inconsistent with international law. $^{79}$

The importance of the constitution in interpreting international trade laws was highlighted in the case of The Chairman on the Board on Tariffs and Trade $v$ Brenco. ${ }^{80}$ In this case, the court aquo had agreed with the respondent's allegation that the conduct of the Board on Tariffs and Trade, the predecessor to ITAC, had not complied with the rules of natural justice before anti-dumping duties were imposed. Upon appeal to the Supreme court of Appeal, it was held that the guiding question to ask in that context is: "Did the respondents receive in good time information that was sufficient for the purposes of defending themselves?"81 If the answer is in the affirmative, then procedural fairness would have been observed in an anti-dumping context. $^{82}$ Therefore, in the absence of precise legislation, South African courts will have to look at International law and International provisions for guidance. In pursuit of the above constitutional imperative, South African courts must interpret laws and any legislation in such a manner that the interpretation promotes the object and purport of the country's bill or rights by infusing the values of human dignity, equality and freedom. ${ }^{83}$ These values are important to anti-dumping law because it is not possible for South

1993 Constitution" 199419 SAYIL 5; Olivier "Interpretation of the Constitutional Provisions Relating to International Law" 20036 PELJ 26; and Scholtz "A Few Thoughts on Section 231 of the South African Constitution" 200429 SAYIL 202.

75 Per s 231(3) of the Constitution.

$76 \mathrm{~S} 231(4)$ of the Constitution.

$\mathrm{S} 231(5)$.

$\mathrm{S} 232$ of the Constitution.

$\mathrm{S} 233$ of the Constitution.

20014 SA 511 (SCA).

The Chairman on the Board on Tariffs and Trade $v$ Brenco supra par 19.

Ibid.

See specifically ss 36 and 39 of the Constitution. 
Africans to lead a dignified life while cheap imports threaten the establishment and development of the local industry, which may be a source of livelihood and economic development for the betterment of the lives of all. ${ }^{84}$

\section{The relevant statutory enactments}

The Customs and Excise Act, ${ }^{85}$ the predecessor legislation to the ITAC Act, still plays a major role in dumping and anti-dumping matters since it gives guidelines to the International Trade Administration Commission as to the maximum tariff to be imposed on dumped imports. ${ }^{86}$ Chapter VI of the Customs and excise Act deals, among other things, with anti-dumping duties. The Act provides that the Minister of Finance may from time to time, by notice in the Gazette, withdraw anti-dumping duties in accordance with the request from the Minister of Trade and Industry. ${ }^{87}$

However, the ITAC Act is the most important statute in the present context because it defines related terms such as dumping, ${ }^{88}$ normal value ${ }^{89}$ export price $^{90}$ etcetera. The Act also deals generally with how investigations into alleged dumping may be conducted and how confidential information may be dealt with. Because South Africa is a member of SACU, ${ }^{91}$ the practical reality is that any dumping and anti-dumping investigation now assumes a SACUwide ambit, and local industry which is being harmed or threatened with harm now refers to the specific industry in the SACU region.

Because there are detailed provisions in the current ITAC Act and the regulations relating to confidentiality of information in anti-dumping

84 The preamble to the Constitution clearly spells out that one of the aims of the Constitution is to improve the quality of life of all citizens and free the potential of each person.

8591 of 1964, reprinted in the Government Gazette G/ADP/N/I/ZAF/I on 8 December 1995. Chapter VI of the Act deals specifically with matters pertaining to anti-dumping duties.

86 For an overview of how the anti-dumping provisions of the predecessor to the ITAC Act, namely the Board on Tariffs and Trade Act 107 of 1996 (BTT Act), were applied in practice for the very first time by a South African court, see Osode 200322 Penn State International Law Review 23-32; and Osode "The Scope of Interested Parties Rights to Procedural Fairness in the Enforcement of South African Anti-Dumping Law: Board on Tariffs and Trade and Others v Brenco Inc and Others" 200216 Speculum Juris 290.

87 S 56(2) of the Customs and Excise Act 91 of 1964.

88 Defined as the introduction of goods into the commerce of the Republic or the Common Customs Area at a price contemplated in s 32(a)(2) of the ITAC Act that is less than the normal value, as defined in that Act, of those goods.

89 Defined in s 32(2)(b)(i)-(ii) of the ITAC Act as encompassing the ordinary price at which goods intended for export are sold in the exporting country's domestic market or if the price is not easily ascertainable, the reasonable cost of producing and placing the product on the domestic market of the exporter.

90 Defined in s 32(2)(a) of the ITAC Act as the price actually paid or payable for goods sold for export, net of all taxes, discounts and rebates actually granted and directly related to that sale.

91 According to the SACU website www.sacu.int (accessed 2010-06-11) SACU, the world's oldest customs union, came into existence on 11 December 1969 with the signature of the Customs Union Agreement between South Africa, Botswana, Lesotho, Namibia and Swaziland. The final constitutive Agreement of the present SACU Customs Union consists of the 1910, 1969 and 2002 SACU Agreements. 
investigations, ${ }^{92}$ it is likely that the pertinent provisions of South Africa's Promotion of Access to Information $\mathrm{Act}^{93}$ will play a major role.

Generally, with specific reference to information held by the state, individuals can apply for access to such information without giving their reasons for the request. ${ }^{94}$ However, in matters between individuals (and even corporate bodies) a request for access to information in terms of the Act would have to be accompanied by written reasons. In all material circumstances, the state must provide access to such information unless the information relates to "financial, scientific or technical commercial information". ${ }^{95}$ There are, however, exceptions to this provision which may remove the protective veil of confidentiality from the specified categories. ${ }^{96}$ The South African case law that has dealt with the exceptions to confidentiality in a dumping/anti-dumping context is the unreported case of Rhone Poulence $v$ Chairman of the Board on Tariffs and Trade. ${ }^{97}$

Information relating to dumping is likely to affect commercial interests and the respondents in anti-dumping investigations are likely to seek refuge in the confidentiality provisions of the Promotion of Access to Information Act. ${ }^{98}$

The provisions of South Africa's Promotion of Administrative Justice Act ${ }^{99}$ relating to giving the parties advance notice and affording them an opportunity to make representations ought to be discussed together with the common-law provisions on same. In terms of the ITAC Act and the attendant regulations, read together with the pertinent provisions of PAJA, the Commission must give parties adequate notice of the proposed administrative action, an opportunity to make representations, a clear statement of the administrative action, notice of the review mechanism and the right to request reasons. ${ }^{100}$ It can now be confidently submitted that the PAJA enshrines the common-law principles of natural justice, including the audi alteram partem and nemo iudex in rem sua rules. ${ }^{10}$

92 S 33 of the ITAC Act, $S 2$ of the current Anti-Dumping Regulations and part B of the proposed Anti-Dumping Regulations.

2 of 2000.

$94 \mathrm{~S} 11(1)(3)(\mathrm{a})$ of the Promotion of Access to Information Act, 2000.

$95 \mathrm{~S} 36(1)(\mathrm{c})$ of Act 2 of 2000.

96 See the exceptions enumerated in s 46 of the same Act.

97 Case no. 98/6589T 26.

98 See $\mathrm{s} 36$ of Act 2 of 2000.

99 Act 3 of 2000 (hereafter "PAJA"). This Act was promulgated pursuant to the constitutional provision in $\mathrm{s} 33$ of the South African Constitution which affords everyone the right to a just administrative action that is just, reasonable and procedurally fair.

$100 \mathrm{~S} 3(2)(\mathrm{b})$ of PAJA.

101 According to Hoexter Adminstrative Law in South Africa (2007) 326-328, the audi alteram partem rule implies that people are given an opportunity to participate in the decisions that will affect them and obtain an opportunity to influence the outcome of those decisions. On the other hand, the nemo iudex in rem sua principle is famously referred to as the rule against bias and ensures that a hearing is held before an impartial tribunal or in the context of dumping/anti-dumping, the ITAC must ensure a complete absence of bias against any of the interested parties. 


\section{INTRODUCING THE INTERNATIONAL TRADE ADMINISTRATION AMENDMENT BILL, 2005}

\section{Background and context}

Although South Africa's Anti-Dumping Regulations had been in force for only three years, ITAC published extensive proposed amendments to the AntiDumping Regulations. ${ }^{102}$ Most of the proposed amendments to the regulations stem from the proposed amendment of section 32 of the ITAC Act by the International Trade Administration Amendment Bill, $2005 .{ }^{103}$ The Bill's proposed amendments seek to overhaul substantial portions of the dumping and anti-dumping provisions of the ITAC Act. It has been submitted that the proposed amendments are informed by ITAC's past and current experience in administering the Anti-Dumping Regulations, the requirements of the WTO agreements, the decisions by the WTO Appellate Body ${ }^{104}$ as well as policies of the Department of Trade and Industry.

\section{Are the specific impugned Amendments WTO Compliant?}

\section{Confidentiality}

Confidentiality is an important concept ${ }^{106}$ in anti-dumping investigations hence both the current regulations and the proposed amendments make extensive reference to it. ${ }^{107}$ In terms of the present ITAC Act, a person submitting information to the Commission may identify information that is confidential by its nature, ${ }^{108}$ or information which the person wishes to be

102 GN 1606 in GG 29382 of 2006-11-10.

103 See ss $10-11$ of the Amendment Bill.

104 Brink (fn 13 above) 2.

105 Ibid.

106 See Article 6.5 of the Anti-Dumping Agreement and s 36 generally of the Promotion of Access to Information Act 2 of 2000 . The concept is important because it may be possible that disclosure of certain information may afford a significant competitive advantage to a business rival or disclosure of certain information may have a significantly adverse effect upon a person supplying the information.

107 See s 2 of the current Anti-Dumping Regulations and part B - General Provisions of the proposed anti-dumping regulations.

108 In order to establish if information is confidential by its nature, one must be guided by $\mathrm{s} 33$ of the ITAC Act read together with s 36 of the Promotion of Access to Information Act 2 of 2000. Regulation 2 of the current Anti-Dumping Regulations lists management accounts, financial accounts of a private company, actual and individual sales prices, costs of production and importation, actual sales volumes, individual sales prices, information the release of which could have serious consequences for the person that provided such information and information that would be of significant advantage to the competitor as specified categories of information that is confidential by nature. It should be noted that information that is deemed to be confidential by nature will not always be treated as such unless the party seeking to rely on the confidentiality expressly indicates that the information is confidential. 
treated as confidential. ${ }^{109}$ The ITAC Act further provides that the claim of confidentiality must be accompanied by a written statement in the prescribed form explaining why the information in question is confidential by nature and further, if the information is not confidential by its nature, why it should be treated as confidential. ${ }^{110}$ The statement referring to the confidential nature of the information must be in the form of a non-confidential summary or a sworn statement explaining why it is impossible to comply with providing an abstract. ${ }^{111}$

Notwithstanding the above clear directive as pointed out by the ITAC Act, the proposed amendment brought about by the Bill only requires a person seeking to rely on the confidentiality provisions of the ITAC Act to submit a plain statement of reasons why a non-confidential summary cannot be provided.

The conclusion that can be drawn from the tenor of the proposed amendment is that it will no longer be a requirement that an explanation of one's failure to comply with subparagraph (ii) of subsection 2(b) of the ITAC Act should be in the form of a sworn statement. This flies in the face of standing WTO provisions and even conflicts with the ITAC Act itself. It is submitted that the requirement of a sworn statement should be retained to emphasize the juridical importance of the statement in terms of subparagraph (ii) of section 33(2)(b) of the ITAC Act.

The proposed amendments to the Anti-Dumping Regulations do not help cure the deficiencies in the Amendment Bill as far as confidentiality is concerned. Apart from being repetitive, the provision in proposed AntiDumping Regulation 2, requiring the party to indicate in each instance where confidential information has been omitted and give reasons thereof is not particularly helpful. This point is raised here because the previous subsection in the current regulations already contains the same wording. ${ }^{113}$

In terms of the ITAC Act, if the Commission decides that information is not confidential by nature or ought not to be treated as confidential, it must inform the party concerned about its decision and indicate that the information will be disregarded in determining the merits of an application or other matter in question. ${ }^{114}$ The Amendment Bill repeals this important provision and the wisdom of such an amendment is questionable. ${ }^{15}$ The amendment is questionable because it now leaves ITAC with too much discretion to decide what is confidential by nature and what is not. The right to be informed about exclusions of information based on confidentiality is now lost to the party who seeks to rely on such according to the Amendment

\footnotetext{
Per s 33(1)(a)-(b) of the ITAC Act.

S 33(2)(a)(i) and (ii) of the ITAC Act.

S 33(2)(b) of the ITAC Act.

12 See $\mathrm{s} 11$ of the International Trade Administration Amendment Bill, 2005.

13 See Brink (fn 13 above) 13.

114 S 34(3)(b) of the ITAC Act.

115 The Bill repeals ss 34 (determination by the Commission), 35 (proceedings in contested claims), 36 (disclosure of information) and 37 (restricted use of information) of the ITAC Act.
} 
Bill. The proposed Anti-Dumping Regulations do not remedy the situation because proposed regulation 2 baldly and laconically states that the Commission will disregard any information indicated to be confidential that is not accepted as confidential by the Commission in terms of section 34 of the main Act. This is a surprise inclusion in a regulation that purports to respond to a section of a statute that has been repealed. In other words, the regulatory provision is not in synch with the provisions of the Act unless it anticipates that the Amendment Bill will not see the light of day. ${ }^{116}$

Finally, the proposed Anti-Dumping Regulations provide that if a party fails to provide a non-confidential version of the purported confidential information or does not provide reasons for the confidentiality, such information will be disregarded only if the failure to provide a summary or reasons for confidentiality materially affects the ability of interested parties to defend their interests. ${ }^{117}$ The question that then immediately arises is: "Who will determine whether such failure materially affects the ability of interested parties to defend their interests? ${ }^{, 18}$ If it means the buck stops with the ITAC, then this does not augur well for justice and equity as far as the party ruled against is concerned. It is submitted that the provisions in the current regulations be retained as they are since the proposed ones seem to be an exercise in wordiness and superfluity rather than a pursuit of WTO compliance.

\section{Investigations}

Generally, and in the absence of special circumstances, an anti-dumping investigation shall only be initiated upon acceptance of a written application by or on behalf of the domestic industry (emphasis added). ${ }^{19}$ Only in special circumstances will investigating authorities conduct a self-initiated investigation on behalf of the domestic industry. ${ }^{120}$ Under this special provision, the authorities will only proceed if they have sufficient evidence of dumping, injury and a causal link, to justify the initiation of an investigation. ${ }^{121}$ However, there is no mention of "special circumstances"122 in South Africa's proposed anti-dumping regulations and this is a cause for

$116 \mathrm{~S} 34(3)(\mathrm{b})$ of the ITAC Act is set to be repealed by the Amendment Bill but the new Regulations which one would expect to be mimicking the position espoused by the Amendment Bill do not seem to take into account the fact that the pertinent provision has been repealed.

117 This is materially different from the current Regulations which only provide that such material will be returned to the originator and do not go further to point out that the failure to comply must materially affect the ability of interested parties to defend their interests.

118 See also Brink (fn 13 above) 4.

119 Article 5.1 of the Anti-dumping Agreement. It must be noted that in terms of the current South African Anti-Dumping Regulations and the proposed ones, the words "domestic industry" are replaced by "SACU industry" to properly indicate that "domestic industry" now has a wider meaning which includes industries in Swaziland, Lesotho, Botswana and Namibia in addition to those in South Africa.

120 Article 5.6 of the Anti-Dumping Agreement.

121 Ibid.

122 Ibid. 
concern. It is ideal that the regulations retain the tenor of the relevant WTO provision, namely the Anti-Dumping Agreement so as to avoid the abuse of self-initiation provisions by overzealous investigating authorities. Retaining the "special circumstances" provision would ensure that the standard of proof of the existence of dumping remains high. This would dissuade the ITAC from embarking on unjustified and WTO-inconsistent self-initiated investigations.

South Africa's proposed Anti-Dumping Regulations seek to set out the procedure in terms of which the ITAC will initiate investigations and reviews sua ponte. ${ }^{123}$ It has been argued that there is no need for such a provision in the regulations because it is superfluous. ${ }^{124}$ The main reason advanced for the superfluity is that ITAC and its predecessor, the Board on Tariffs and Trade (BTT) have never self-initiated an investigation. ${ }^{125}$ It is submitted that such criticism is misplaced because there is no harm in anticipating a problem. There shall come a time when the self-initiation provisions will come in handy and the ITAC will have to use them. The fact that there has never been a self-initiated investigation by the ITAC does not totally extinguish the possibility of the adoption of such a procedure in the foreseeable future.

The relevant regulation dealing with self-initiated investigations imposes stylistic problems. ${ }^{126}$ The first part of the regulation makes mention of interim, new shipper, sunset or anti-circumvention reviews which are generally only initiated at the instigation of the domestic industry subject to outlined exceptions. ${ }^{17}$ However, proposed Anti-Dumping Regulation 3.3(b) has a fatal stylistic problem in that it only refers to interim reviews and leaves out new shipper and sunset reviews. Such an omission is inexplicable when one considers the fact that the current regulations contain a provision that encapsulates all the three forms of reviews in the specific context of selfinitiation. ${ }^{128}$ Such a stylistic deficiency would be in conflict with the relevant WTO provisions. ${ }^{129}$ It is submitted that the deficiency be remedied by retaining the pertinent provision in the current regulations, which seem to be WTO compliant.

${ }^{123}$ This terminology is attributed to Brink (fn 13 above) 5 . It is possible to embark on an investigation of this nature and its justification has a textual basis in Article 5.6 of the AntiDumping Agreement.

124 Brink (fn 13 above) 5.

125 Ibid.

126 See specifically proposed Anti-Dumping Regulation 3.2 and 3.2(b).

127 The relevant exceptions are outlined in regulations 3.3(a)-(b) of the proposed Anti-Dumping Regulations.

128 See Regulation 3.3 of South Africa's current Anti-Dumping Regulations.

129 Generally encapsulated in Article 5 of the Anti-Dumping Agreement. 


\section{Termination based on de minimis margins}

As soon as the investigating authorities ${ }^{130}$ are satisfied that there is no sufficient evidence of either dumping or injury to justify proceeding with the case, an application for dumping shall be rejected and the investigation terminated. $^{131}$ This would be a classic case of a de minimis ${ }^{132}$ dumping margin or an instance where the volume of dumped imports, actual or potential or the injury, is negligible. ${ }^{133}$ It is important to point out that neither the ITAC Act nor the current regulations actually make reference to termination of investigations on the basis of de minimis dumping margins or negligible volumes of imports. The Amendment Bill is also silent on such an important WTO provision.

However, on an interesting note, the proposed Anti-Dumping Regulations do incorporate the pertinent provisions of the WTO Anti-Dumping Agreement albeit in a muddled manner. The ideal would be to go through every provision of the Anti-Dumping Agreement and draft regulations that comply with the law to the letter. This would reduce the high incidences of conflict between the Anti-Dumping Agreement and the Regulations. Very disturbingly, the proposed Anti-Dumping Regulations provide that an investigation shall not be initiated or an investigation shall be terminated if the margin of dumping is de minimis or the import volumes are negligible. ${ }^{134}$ The part relating to not initiating an investigation because import volumes are negligible is WTO-inaccurate/incorrect. ${ }^{135}$ The position is untenable because logically speaking, there is no way it can be determined prior to the initiating of an investigation whether import volumes are negligible. Attempting to defend the veracity of the above statement would be tantamount to deliberately distorting the law as clearly spelt in Article 5.8 of

130 In South Africa, these authorities are members of the International Trade Administration Commission (ITAC), established in terms of $s \quad 7$ of the ITAC Act. The functions of the Commission in terms of $\mathrm{s} 15$ of the ITAC Act include among others, investigating dumping and anti-dumping complaints as provided for in s 26 of the ITAC Act.

131 Article 5.8 of the Anti-Dumping Agreement.

132 The principle that comes into play here is that embodied in the maxim de minimis non curat lex, which means "the law does not concern itself with trifles". The principle was first applied in the context of South African criminal law in the case of S v Kgogong 19803 SA 600 (A). In anti-dumping matters, the implication is that investigating authorities should not proceed with an investigation of alleged dumping if the magnitude of dumping is insignificant and hence it is presumed that such dumping will not cause any material injury and not actionable. An insignificant dumping margin is characterised as one that is less than $2 \%$ (Article 5.8 of the Anti-Dumping Agreement). The de minimis concept was referred to and discussed in the disputes discussed in paragraph 4 below. For a conspectus of academic views on the concept from a WTO perspective, see Rude and Gervais "Biases in Calculating Dumping Margins: The Case of Cyclical Products" 200931 Review of Agricultural Economics 122-142; Epstein "The Moral and Practical Dilemmas of an Underground Economy" 1994103 Yale Law Journal 2157-2177; Benz "Below Cost Sales and the Buying of Market Share" 199042 Stanford Law Review 695-744; and Jackson "The Jurisprudence of International Trade: The Disc Case in GATT" 1978 The American Journal of International Law 747-781.

133 Article 5.8 of the Anti-Dumping Agreement.

134 See Article 4 of the proposed Anti-Dumping regulations.

135 See Brink (fn 13 above) 5. 
the Anti-Dumping Agreement. ${ }^{136}$ The proposed Anti-Dumping Regulations should therefore be amended accordingly to reflect the fact that termination on the basis of negligible imports and/or a de minimis dumping margin will only be contemplated after an investigation has been conducted. This is the only WTO compliant approach that is in sync with Article 5.8 of the AntiDumping Agreement.

\section{Representations}

In this article thus far it has been indicated that there are very few instances where positive statements were made about South Africa's new antidumping regime. On a positive note, South Africa's proposed Anti-Dumping Regulations anticipate representation of an interested party in anti-dumping investigations by an outsider. ${ }^{137}$ Such representation is available during an investigation or a review. It should be pointed out that such a provision is a first for South Africa since it is not directly provided for in the current regulations or the WTO Agreement. The participation of the outsider is dependent on the represented party complying with three obligations. First, the party must provide the Commission with a letter of appointment, detailing the identity of the representative, scope and duration of mandate. Secondly, should the interested party be desirous of terminating the mandate, the termination must be done in writing. Thirdly, once the representative has been appointed all communication between the Commission and the interested party will take place through the representative. Such a provision is welcome since it advances the scope of the interested parties' right to procedural fairness. ${ }^{138}$

\section{Interested party hearings ${ }^{139}$}

In a bid to comply with the pertinent WTO provisions on the right of interested parties to present their cases, ${ }^{140}$ South Africa's proposed Anti-

${ }^{136}$ Brink graphically illustrates the extent of the incorrectness of the pertinent provision of the proposed Anti-Dumping Regulations (5-6) wherein he gives an example of an anti-dumping application lodged against five countries contributing negligible values of imports individually. It will only be possible to know if the import volumes are negligible or the margin is de minimis after investigating and establishing how much each country contributes to the volume of dumped imports.

137 See Article 5 of South Africa's proposed Anti-Dumping Regulations. This first for South Africa is not echoed anywhere else in another jurisdiction that the present writer is aware of. Even the WTO Anti-Dumping Agreement does not seem to have captured this form of representation directly.

138 On the scope of interested parties' right to procedural fairness, see generally Osode 2002 16 Speculum Juris 290.

139 In terms of Article 6.11 of the Anti-Dumping Agreement, interested parties shall include a producer/exporter of the product under investigation, a business association a majority of whose members are importers or exporters of the product in question, the government of the exporting member and producers of the like product in the importing member. It is worthwhile to take particular notice that the heading "Interested Parties Hearings" is a creature of Regulation 6 of the amended Anti-Dumping Regulations.

140 The relevant provision is Article 6.2 of the Anti-Dumping Agreement. 
Dumping Regulations now contain a single regulation dealing with "interested parties' hearings". ${ }^{141}$ This is unlike the previous case where the regulations contained two separate provisions dealing with oral "hearings" and "adverse party meetings". ${ }^{12}$ Coalescing the two regulatory provisions does not seem to be appropriate in this context especially when due regard is paid to the fact the equivalent WTO provision seeks to afford interested parties an opportunity to air opposing views and rebut arguments proffered taking into account the need to observe confidentiality. ${ }^{143}$ The proposed AntiDumping Regulations are conspicuous by their silence on issues of accommodating opposing views and rebuttals and the question of preserving confidentiality. ${ }^{144}$ Such issues are adequately catered for in the current Regulations which in all due respect should not be amended since their provisions on same are more than adequate, not to mention WTO compliant.

There are other concerns about the provision relating to interested parties. First, parties will be informed 21 days prior to the hearing of the existence of such a hearing yet they are supposed to submit a detailed outline of the agenda, attendees and a detailed version of the information to be presented at the hearing at least 14 days prior to the date of the hearing. ${ }^{145}$ Of more serious concern is the fact that at least 7 days prior to date of the hearing, the Commission shall provide interested parties who have complied with the 21 days requirement, a list of attendees, an outline, agenda for the hearing and an allocation of time among interested parties. ${ }^{146}$ The Regulations require a "detailed agenda" and a "detailed version" including a "nonconfidential version" if applicable from interested parties. This condition is rather onerous on the part of interested parties and sets the bar higher than what is prescribed by the WTO, ${ }^{147}$ which allows for information to be reproduced in writing and subsequently made available to other interested parties. ${ }^{148}$ If interested parties have to be made to supply detailed accounts of all the issues within seven days, this requirement would place an onerous burden on them. It would be more ideal to allow the parties to give an oral outline of the issues at stake and then give them more time, say at least seven days and at most 14 days to prepare a written account. If a party fails

141 Regulation 6 of the proposed Anti-Dumping Regulations.

142 See Regulations 5 and 6 respectively of the current Anti-Dumping regulations.

143 Per WTO Anti-Dumping Agreement Article 6.2.

144 The confidentiality deficiency is partly cured by the fact that there is an express reference to confidentiality issues in proposed Regulation 2, as previously discussed in a rather different context in paragraph 321 above, but it submitted this is not adequate.

145 Per Regulation 6 paragraph 2 of the proposed Anti-Dumping regulations.

146 Ibid.

147 However, this is not WTO-illegal and this may be an advantage to a litigant in South Africa because WTO Agreements are generally not enacted into South Africa's domestic legislation. For another example in a WTO context in which a WTO member was allowed to raise the bar higher than the WTO standard, see Ndlovu "The EC-Asbestos Dispute and Its Implications for a Transforming SADC: Is the Dust Refusing to Settle?" 200621 SA Public Law 246 256-257.

148 At least at the WTO level (per Article 6.3 of the Ant-Dumping Agreement), authorities can take judicial notice of oral information as long as it is subsequently reduced to writing and later made available. 
to submit the written version within the stipulated extended time, then it would only be fair to disregard the oral information. ${ }^{149}$

\section{INTERNATIONAL TRENDS AND WTO JURIS- PRUDENCE}

From the discussion above, it is apparent that while the intended amendments are welcome, they were not well drafted hence the Bill has been shelved for a while. However, a worrisome development has been the fact that despite the Bill having been withdrawn, South Africa's Minister of Trade and Industry has still gone ahead and published draft Regulations for public comment. In this article, the author have tried to point out the weakness in the anti-dumping regulatory framework against a WTO backdrop, namely the provisions of the Anti-Dumping Agreement. In this section, the author further criticize the regulatory framework with reference to selected WTO disputes and a few examples from other jurisdictions.

In procedures where an investigation has to be terminated because the margin of dumping is de minimis or the volume of dumped imports, actual or potential, or the injury is negligible, the WTO clearly spells out that an investigation is a prerequisite. South Africa's new regulatory regimes seem to gloss over this in sharp contrast to the practice in other WTO member states. In Argentina, Bolivia, Brazil, Canada, Chile and Colombia the antidumping laws are clear that in order to rely on the de minimis provisions, an investigation has to be conducted first. ${ }^{150}$ To show the importance of sticking to the WTO standard as the basic one, the regulatory framework and practice in countries such as Dominican Republic, Ecuador, El Salvador Guatemala, Honduras, Jamaica, Mexico, Nicaragua and Panama simply prescribe the WTO standard. ${ }^{151}$

It is submitted that rather than coming up with elaborate Anti-Dumping Regulations that do not stand up to the test of WTO scrutiny, South Africa should be guided by the WTO provisions and stick to the prescriptions of the Anti-Dumping Agreement.

In the case of US - Drams, ${ }^{152}$ the panel considered that the scope of Article 5.8 of the Anti-Dumping Agreement (de minimis standard) is limited to applications for investigations as set out in that Article and does not extend to other forms of duty assessment procedure. Similarly, in the 1992-1993 US anti-dumping investigations of flat-rolled steel products, the United States found that Belgian imports of cold-rolled steel products were negligible and

149 Such an approach would not only be WTO compliant, but would also ensure that the parties' right to procedural fairness is guaranteed.

150 See Free Trade Area of the Americas - FTAA "Compendium of Anti-Dumping and Countervailing Duty Laws in the Western Hemisphere" 1-2 http://www.ftaa-alca.org/ Wgroups/WGADCVD/english/031301.asp (accessed 2009-09-14).

151 FTAA (fn 150 above) 2-4.

152 Panel Report, United States - Anti-Dumping Duty on Dynamic Random Access Memory Semi-Conductors (DRAMS) of One Megabit or above from Korea WTT/DS99/R, adopted on 19 March 1999. 
thus not a cause of injury to the United States industry. ${ }^{153}$ The latter case refers to a record that demonstrates the importance of conducting appropriate investigations before concluding that margins or import volumes are negligible or de minimis.

The Panel Report on Argentina - Poultry Anti-Dumping Duties ${ }^{154}$ considered that, by definition, "interested parties" necessarily have an interest in the investigation and should therefore be notified if they are known to the investigation authorities. This measure will enable the interested parties to present opposing views or rebut arguments offered while taking into account the need to preserve confidentiality. ${ }^{155}$ This position, unfortunately, is not part of South Africa's intended amendments to the Anti-Dumping Regulations as previously pointed out in this article. ${ }^{15}$

The importance of interested parties' rights was further emphasized in the Panel Report on US - Corrosion-Resistant Steel Sunset Review. ${ }^{157}$ In this dispute, it was stated that the right of interested parties to submit information in a sunset-review cannot be unlimited. The fact that the right can be limited in a sunset-review context should not be interpreted to mean that the right is trivialized - it must be granted at all costs before the question of its limitation arises. ${ }^{158}$ Finally, in the Panel Report on Egypt - Steel Rebar, ${ }^{159}$ it was emphasized that the language of the provision at issue creates an obligation on the investigation authorities to provide opportunities for interested parties to defend their interests. South Africa therefore risks WTO sanction and costly litigation if it leaves its regulatory framework unclear and noncommittal as far as the joinder of interested parties is concerned. The author reiterate that interested party hearings should and must include both oral and adverse party hearings as was the case in the previous regulatory regime, namely the 2003 Regulations. Procedural adjustments in this regard would make South African laws WTO compliant.

This article expressed reservations about the 21 days notice of an impending hearing and the 14 day period within which parties ought to have submitted detailed responses to an anti-dumping application. Although the Anti-Dumping Agreement does not require investigating authorities to set time limits with specific regard to the presentation of arguments and

153 See Certain Flat-Rolled Carbon Steel Products from Argentina, Australia, Austria, Belgium, Brazil, Canada, Finland, France, Germany, Italy, Japan, Korea, Mexico, the Netherlands, New Zealand, Poland, Romania, Spain, Sweden and the United Kingdom http://www.usitc. gov/publications/docs/pubs/701_731/PUB3471.PDF (accessed 2009-09-14).

154 Panel Report, Argentina - Definitive Anti-Dumping Duties on Poultry from Brazil WT/DS241/R, adopted 19 May 2003, DSR 2003: V, 1727.

155 Per Article 6.2 of the Anti-Dumping Agreement.

156 See paragraph 325 above.

157 Panel Report United States - Sunset Review of Anti-Dumping Duties on CorrosionResistant Carbon Steel Flat Products from Japan, WTT/DS244/R, adopted 9 January 2004, modified by the Appellate Body Report, WTDS244/AB/R, DSR 2004:I, 85.

158 Panel Report United States - Sunset Review of Anti-Dumping Duties on CorrosionResistant Carbon Steel Flat Products from Japan par 7.29.

159 Panel Report Egypt - Definitive Anti-Dumping Measures on Steel Rebar from Turkey, WT/DS211/R adopted 1 October 2002, DSR 2002: VII, 2667. 
evidence during the final stage of the investigation, ${ }^{160}$ the most important time limit is the one provided for in Article 6.1. In terms of the specific article, exporters shall be given at least 30 days to reply to questionnaires. ${ }^{161} \mathrm{It}$ is submitted that the 30-day period should be used as a point of reference by the South African authorities in setting related time limits rather than the onerous 21 days. It is indeed within the powers of investigating authorities and in the interest of orderly administration that investigation authorities do, and must establish such deadlines. ${ }^{162}$ The Appellate Body further emphasized that the deadlines are "not necessarily absolute and immutable". ${ }^{163}$ This is because Articles 6.1 and 6.2 of the Anti-Dumping Agreement do not provide for indefinite rights to enable respondents to submit relevant evidence, attend hearings, or participate in the enquiry as and when they choose. ${ }^{164}$

Although this article did criticize the South African anti-dumping provisions relating to confidentiality in paragraph 32 above, when benchmarked against some WTO disputes referred to and discussed above, South Africa's provisions on same do measure up to a large extent. It is important to point out that in the Panel Report on Argentina-Ceramic Tiles, the panel emphasized that the purpose of the non-confidential summaries is to inform the interested parties so as to enable them to defend their interests. ${ }^{165}$ The implication is that investigating authorities should strive not to base their findings on confidential information. ${ }^{166}$ However, on a negative note, South African Regulations do not expressly state that authorities shall require interested parties to provide a statement of the reasons why it is not possible to furnish a summary of confidential information. An express provision would ensure that there is no blanket flagging of information as confidential in order to escape regulatory scrutiny. It has been held previously that any meaningful interpretation of the provision dealing with the purpose of non-confidential summaries, namely Article 6.5.1 of the Anti-Dumping Agreement, must

160 See Article 6.1 of the Anti-Dumping Agreement. See also Panel Report, Guatemala Definitive Anti-Dumping Measures on Grey Portland Cement from Mexico, WT/DS156/R, adopted 17 November 2000, DSR 2000:XI, 5295.

161 See Article 6.1.1 of the Anti-Dumping Agreement

162 This remark is attributed to the Appellate body which concurred with the panel in the course of considering an appeal against the decision in United States - Anti-Dumping Measures on Certain Hot-Rolled Steel Products from Japan, WT/DS184/R, adopted 23 August 2001 and modified by the Appellate Body report, WT/DS184/AB/R, DSR 2001: X, 3769.

163 United States - Hot-Rolled Steel par 417.

164 Appellate Body Report United States - Sunset Reviews of Anti-Dumping Measures on Oil Country Tubular Goods from Argentina, WT/DS268/AB/R, adopted 17 December 2004.

165 Panel Report Argentina -Definitive Anti-Dumping Measures on Imports of Ceramic Floor Tiles from Italy, WT/DS189/R, adopted 5 November 2001, DSR 2001: XII, 6241.

166 This view would sharply contrast with the Appellate Body view in Thailand - Anti-Dumping Duties on Angles, Shapes and Sections of Iron or Non-Alloy Steel and H-Beams from Poland, WT/DS122/AB/R, adopted 5 April 2001, DSR 2001: VII 2701 wherein it was held that anti-dumping investigations involve commercial activities hence the determination of injury must be based on the totality of evidence hence confidential information may be usable. 
impose such an obligation on the investigating authorities. ${ }^{167}$ It is submitted that the relevant South African regulatory framework must be amended to capture the above WTO compliant proposition clearly.

\section{CONCLUSION}

From the foregoing discussion and critique, it can now be confidently surmised that the proposed amendments, sought to be introduced by the Amendment Bill and the new Regulations, are to a large extent not WTO compliant. Such a conclusion is reached through a comparative analysis of South Africa's regulatory regime against WTO backdrop, namely the AntiDumping Agreement and the pertinent disputes. While the Anti-Dumping Agreement does have provisions that talk directly to confidentiality, de minimis provisions, interested parties, and notice periods and so on, the way these specific issues are catered for in the South African regulatory framework leaves a lot to be desired. For instance, why are interested parties given only 21 days to respond to anti-dumping applications when the relevant WTO instrument prescribes at least 30 days? If such regulatory overzealousness is premised on South Africa's autonomy to legislate on its domestic matters, it is submitted that anti-dumping matters and other issues touching on the regulation of trade in goods and services are sui generis, and any legislation passed in that specific regard must take into account the spirit, object and purport of the GATT/WTO. This interpretive approach would obviate unnecessary litigation between South Africa and other WTO members.

On the other hand, the implementation of some of the proposed amendments will result in quicker finalization of investigations and greater transparency. This should be incorporated into South African law and given effect to. However, as previously pointed out in various sections of this article, some of the proposed amendments will have the opposite effect. The author is firmly of the view that several of the amendments are aimed at curtailing the workload of the ITAC and to ensure a speedy finalization of anti-dumping investigations. However, ITAC's overemphasis on the curtailment of procedural matters is counter productive because it leaves South Africa with a porous regulatory regime that is potentially vulnerable to legal challenge and litigation most of the time. Tinkering with the regulations this way is in actual fact symptomatic of a deeper systemic shortfall in the way the Commission is structured. The correct approach would be to address capacity constraints directly rather than come up with a law that may eventually be impugned on the basis of non-WTO compliance. This article makes the concluding point that the envisaged changes will make the law less and less WTO compliant if the shortcomings pointed out herein are not addressed directly and remedied appropriately.

167 Panel Report on Guatemala - Definitive Anti-Dumping Measures on Grey Portland Cement from Mexico (fn 160 above). 